\title{
Untoward effects of pharmacological doses of insulin in early chick embryos: through which receptor are they mediated?
}

\author{
F. de Pablo, E. Hernández, F. Collía and J.A. Gómez \\ Servicios de Endocrinología y Bioquímica, Hospital de la Santa Cruz y San Pablo, Barcelona, Spain
}

Summary. The teratogenic effect of insulin in early vertebrate embryos is controversial and the mechanisms involved are unknown. We studied the effects of pharmacological doses of insulin in chick embryos during the period of differentiation. We compared the effects of insulin with two proinsulins, desoctapeptide-insulin and multiplication-stimulating activity, peptides that have little insulin-like metabolic activity while they have significant growth effects. Chick embryos at $46 \mathrm{~h}$ of development were injected with the different peptides. At $96 \mathrm{~h}$ the mortality and abnormal growth elicited by the peptides were dose-dependent. Considering the indices of lethality $\left(\mathrm{LD}_{50}\right)$ and affected embryos $\left(\mathrm{ED}_{50}\right)$ as $100 \%$ for insulin, proinsulin was $59-66 \%$ as potent as insulin, desoctapeptide- insulin 2-6\% and multiplication-stimulating activity 176-204\%. In the surviving embryos, insulin $(5 \mu \mathrm{g}$, decreased DNA, RNA and protein content by $49 \%, 40 \%$ and $48 \%$ respectively compared with controls. The effects of insulin were not corrected by simultaneous glucose injections. These data suggest that insulin, at pharmacological doses, interferes with embryo development through a non-metabolic pathway, probably via a growth-type receptor.

Key words: Insulin, proinsulin, insulin-like growth factors, multiplication-stimulating activity, insulin effects on growth, embryogenesis, chick embryo.

bryos. Insulin is present in chicken eggs and chick embryos at 2 days of development [19] and specific insulin binding is demonstrable in 3-day embryos [20]. In the chick both insulin and insulin receptors are widespread at 4 days of embryogenesis.

The objective of the present study was to evaluate the effects of very high doses of insulin and insulin analogues (proinsulin, desoctapeptide-insulin and multiplication-stimulation activity peptide), in the microenvironment of the embryo. This initial approach may help us to understand better the role of insulin, insulin-related peptides and receptors in normal and abnormal embryogenesis.

\section{Materials and methods}

\section{Chick embryos and injection procedure}

Fertilized eggs from White Leghorn chickens (Granja Gibert, Cambrils, Tarragona, Spain) were incubated in a forced draft egg incubator at $38 \pm 0.5^{\circ} \mathrm{C}$ and $70-80 \%$ relative humidity. Forty-eight hours after the beginning of incubation (day 2), eggs were transilluminated to locate the air chamber and embryonic area. A hole was drilled into the air space to release the pressure inside the egg, and $1 \mathrm{~cm}^{2}$ of shell over the embryo was removed [21]. Only embryos between stages 11-14 of development (Hamburger and Hamilton classification) [22], verified 


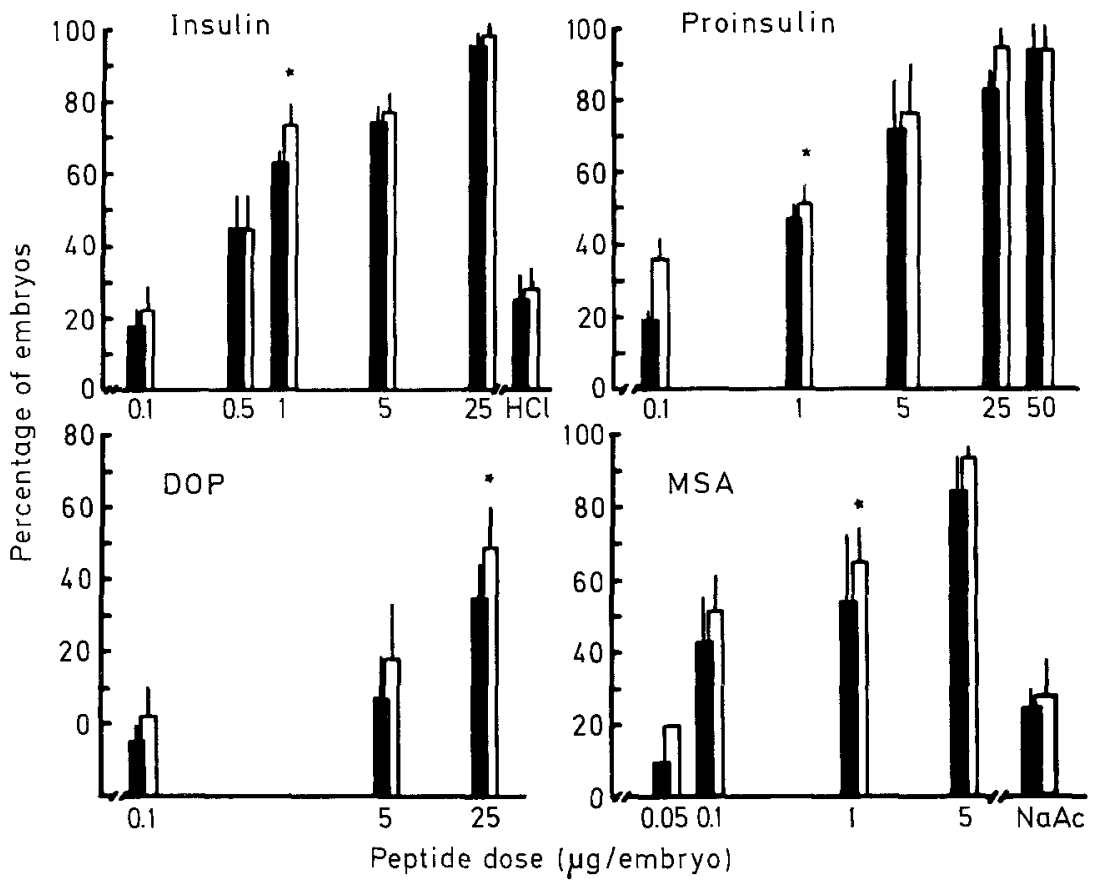

Fig. 1. Mortality and morbidity in chick embryos produced by the different peptides. Embryos were injected at 2 days of development and the percentages of deaths $(\boldsymbol{E})$ and deaths plus abnormalities ( $\square$ ) were evaluated at 4 days. Histograms represent the mean of eight experiments for insulin (total number of embryos ( $\mathrm{n}=333$ ), four for proinsulin $(\mathrm{n}=156)$, two for desoctapeptide-insulin (DOP) $(n=63)$ and four for multiplication stimulating activity peptide (MSA) $(n=126)$. The vertical line on each bar indicates SEM. * indicates the lowest dose of peptide significantly different from control $(p<0.05)$, for deaths plus abnormalities. The mortality dose-response curves fitted in all cases to logarithmic curves with " $r$ " values of 0.61 for MSA $(p<0.02), 0.91$ for insulin $(p<0.0005), 0.94$ for proinsulin $(p<0.0005)$, and 0.79 for DOP $(p<0.05)$

through the shell's window ander a stereomicroscope (Bauch and Lomb, Rochester, New York, USA), were used. Peptides (50 ul) were injected using an insulin syringe (B-D Plastipak, Rochelle Park, New Jersey, USA). Substances were gently released on the dorsal surface of the embryo, covering the entire embryonic area. Although the distribution of the injected peptides was not assessed, preliminary ink injections showed that a volume of $50 \mu \mathrm{l}$ appeared to remain at the site of injection when the eggs were kept in the horizontal position for the remaining period of study. The window was sealed with adhesive tape, and the eggs were returned to the incubator for $48 \mathrm{~h}$ until day 4 of development. Groups of approximately ten embryos were injected with each test dose, unless specified otherwise. In each experiment, five to eight doses of the peptides were tested, at least three of which were with insulin (as an internal control). When biochemical parameters were determined, embryos surviving after injection of each dose were pooled; therefore, the number of embryos used varied with the peptide dose and lethal potency.

\section{Polypeptides and controls}

Porcine insulin was purchased from Elanco Products, Indianapolis, Indiana, USA (lot ODY 44C). A stock solution of $1 \mathrm{mg} / \mathrm{ml}$ in $0.01 \mathrm{~N}$ CH1 was neutralized with concentrated $\mathrm{NaOH}$, filtered through a Millipore $(0.22 \mu \mathrm{m}$ low absorption, Millipore Corporation, Bedford, Massachussetts, USA) and kept at $-20^{\circ} \mathrm{C}$. Further dilutions in $\mathrm{NaCl}$ $(155 \mathrm{mmol} / \mathrm{l})$ were prepared the day before the injections. Bovine insulin was purchased from Eli Lilly, Indianapolis, Indiana, USA. Porcine proinsulin (lot $615-70 \mathrm{~N}-279-1$ ) and bovine proinsulin (lot 615 $-2 \mathrm{H} 2-62$ ) were a gift from Dr R. E. Chance (Lilly Research Laboratories). Desoctapeptide - insulin (DOP) from porcine origin (lot 681) was provided by the National Pituitary Agency, Baltimore, Maryland, USA.

All peptides were prepared as described for insulin. The effects of proinsulin were assessed using two different species, porcine and bovine. The bovine proinsulin was used within a few weeks after reconstitution of a lyophilized preparation, while the pork preparation had been stored at $-20^{\circ} \mathrm{C}$ for several months after dilution. It is important to note that conversion to insulin could be favoured under the latter conditions. Both proinsulins, however, produced almost identical effects, so that a significant contribution due to increased insulin contamination appeared unlikely.

Multiplication-stimulating activity peptide (MSA, rat insulin-like growth factor II) was purchased from Collaborative Research, Waltham, Massachusetts, USA. Each $10 \mu \mathrm{g}$ vial (lot 82-235), con- tained $100 \mu \mathrm{g}$ of sodium acetate and was kept lyophylized at $4{ }^{\circ} \mathrm{C}$ until used. Dilutions were made with filtered $\mathrm{NaCl}(155 \mathrm{mmol} / 1)$.

Analytical grade $\mathrm{HCl}$ and sodium acetate were injected as control solutions, in appropriate concentration to match the highest content of the peptide doses in the experimental groups $(0.005 \mathrm{~N} \mathrm{HCl}$ and $1 \mathrm{mg} / \mathrm{ml}$ sodium acetate). Bovine serum albumin (BSA, Sigma, St Louis, Missouri, USA) was diluted in $\mathrm{NaCl}(155 \mathrm{mmol} / \mathrm{l})$. IgG was prepared from normal (Miles Research Laboratories, Elkhart, Indiana, USA) and anti-insulin (lot 624, Department of Pharmacology, University of Indiana) guinea-pig sera. Adsorbtion of these sera to and elution from a protein-A sepharose column allowed recoveries of 4-6 mg/ml IgG. Insulin depletion experiments were carried out by incubating $1 \mathrm{ml}$ of normal or anti-insulin IgG with $20 \mu \mathrm{g}$ porcine insulin (final concentration $1 \mu \mathrm{g} / 50 \mu \mathrm{l}$ ) for $48 \mathrm{~h}$ at $4{ }^{\circ} \mathrm{C}$. This mixture was centrifuged at $1500 \mathrm{~g}$ for $20 \mathrm{~min}$ and $50 \mu \mathrm{l}$ of the supernatant was injected into the embryos.

\section{Embryo mortality and morbidity evaluation}

Embroys were evaluated at $96 \mathrm{~h}$ of development. At this stage the area vasculosa and heart beat were evident macroscopically. When the heart beat was not verified under a stereomicroscope (Bauch \& Lomb), the embryo was considered dead and was discarded. The live embryos were examined to assess the stage of development, stages 23-24 (Hamburger and Hamilton Classification) being considered normal. Embryos less developed (stages 22 or lower) and embryos with macroscopic abnormalities were considered abnormal (stereomicroscopic evaluation revealed mostly microphalmia, body oedema, malformed limbs or tail). The live embryos, normal and abnormal, were dissected from the membranes, washed in saline and kept at $-70^{\circ} \mathrm{C}$ for biochemical determinations.

The $\mathrm{LD}_{50}$ was defined as the dose of each peptide that killed $50 \%$ of the treated embryos and $E D_{50}$ the dose that caused $50 \%$ affected embryos (abnormal + dead). Both parameters were calculated graphically from the dose-response curves and also by microcomputer analysis using a curve-fitting program. The fitness to logarithmic curves was evaluated by calculating the correlation coefficient " $r$ " and the " $t$ " value for $r$. The relative potency of each peptide interfering with development was established by comparison with pork insulin. The dose of porcine insulin which caused $50 \%$ mortality was divided by the corresponding value of the other peptides, and multiplyed by 100 . A similar method was applied to the $\mathrm{ED}_{50}$ values. Differences between the effects of peptides and controls were analyzed using Student's unpaired t-test. 


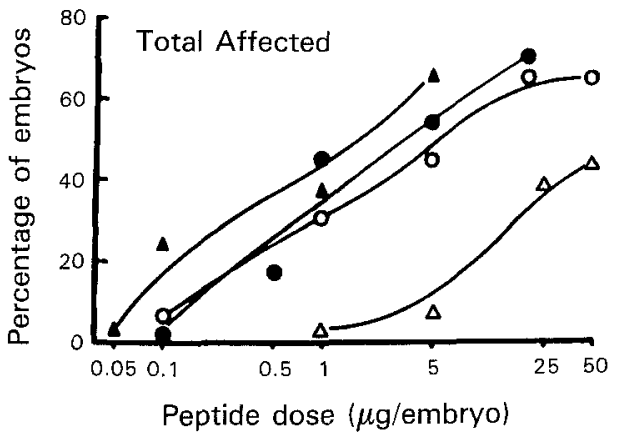

Fig. 2. Comparison of dose-response curves for insulin (proinsulin $\left(\mathrm{O}^{-} \mathrm{O}\right)$, desoctapeptide-insulin (DOP) $(\Delta-\Delta)$ and multiplication-stimulating activity peptide (MSA) ( $\mathbf{\Lambda}-\mathbf{\Lambda})$. Percentage of total affected embryos are based on the same data as Figure 1 after subtraction of non-specific effects. The data fitted to logarithmic curves with " $r$ " values of 0.75 for MSA $(p<0.005), 0.89$ for insulin $(p<0.005), 0.95$ for proinsulin $(p<0.0005)$, and 0.81 for DOP $(p<0.02)$

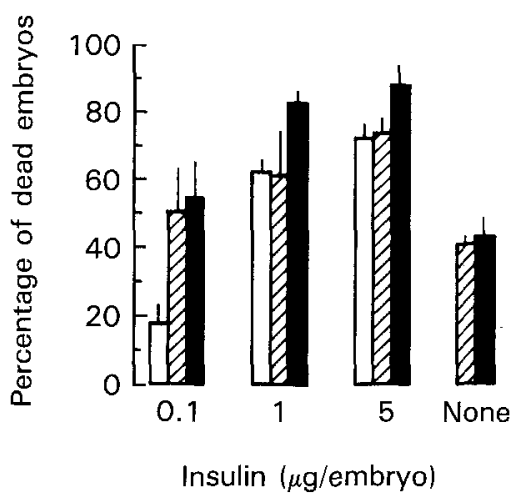

Fig. 3. The influence of glucose on mortality caused by insulin in embryos. Increasing doses of insulin were injected at 2 days of development together with $1(\boldsymbol{E})$ or $10 \mathrm{mg}$ (四) of D-glucose. Insulin alone ( $\square$ ) and D-glucose alone ( $10 \mathrm{mg}$ or $1 \mathrm{mg}$ ) were also injected into control groups. The bars represent the mean of two to three experiments (total number of embryos $=180$ ) and the vertical line on each bar the SEM. There was no significant difference between the mortality effects of $1 \mathrm{mg}$ of glucose plus insulin and $10 \mathrm{mg}$ glucose plus insulin. Compared to insulin alone, at a dose of $0.1 \mu \mathrm{g}$, both ( $\boldsymbol{0}$ ) and (因) were significantly more lethal $(p<0.05)$

\section{Biochemical determinations}

The surviving embryos in each group were thawed on ice, weighed and homogenized in four volumes of cold phosphate buffered saline (pH 7.5) twice for $30 \mathrm{~s}$ using a homogenizer (Ultra-Turrax, Janke \& Kunkel, Staufen i. Breisgau, FRG). The homogenate was centrifuged at $800 \mathrm{~g}$ for $10 \mathrm{~min}$ at $4{ }^{\circ} \mathrm{C}$ and the supernatant was used for determination. Proteins were determinated by the method of Bradford [23]. A simplified micromethod using ethidium bromide was carried out to measure DNA and RNA [24]. Standard DNA from calf thymus, type II, and protease, type XIV, were purchased from Sigma and RNA-ase, type A, from Boehringer, Mannheim, FRG.

\section{Results}

\section{Abnormal development in insulin-treated embryos}

Increasing doses of porcine insulin $(0.1-25 \mu \mathrm{g} / \mathrm{embryo})$ were injected into chick embryos at 2 days of development. Lethality and abnormal or retarded growth in embryos evaluated at 4 days were dose-dependent
Table 1. Indices of lethality $\left(\mathrm{LD}_{50}\right)$ and affected embryos $\left(\mathrm{ED}_{50}\right)$

\begin{tabular}{|c|c|c|c|c|}
\hline & \multicolumn{2}{|l|}{$\mathrm{LD}_{50}$} & \multicolumn{2}{|l|}{$\mathrm{ED}_{50}$} \\
\hline & ( $\mu \mathrm{g} /$ embryo $)$ & $(\%)$ & ( $\mu \mathrm{g} /$ embryo) & $(\%)$ \\
\hline Insulin (pork and beef) & 0.7 & 100 & 0.4 & 100 \\
\hline $\begin{array}{l}\text { Proinsulin (pork and } \\
\text { beef) }\end{array}$ & 1.2 & 59 & 0.6 & 66 \\
\hline DOP (pork) & 38 & 2 & 7 & 6 \\
\hline MSA & 0.4 & 176 & 0.2 & 204 \\
\hline
\end{tabular}

Percentages expressed as relative potency with respect to insulin, based on dose-response curves without correcting for the non-specific effects

Table 2. DNA, RNA and protein content in embryos after insulin, proinsulin or control $\mathrm{HCl}$ injections

\begin{tabular}{|c|c|c|c|c|}
\hline $\begin{array}{l}\text { Injection } \\
\text { ( } \mu g / \text { embryo) }\end{array}$ & $\begin{array}{l}\text { DNA } \\
(\mu \mathrm{g} / \mathrm{embryo})\end{array}$ & $\begin{array}{l}\text { RNA } \\
(\mu \mathrm{g} / \text { embryo })\end{array}$ & $\begin{array}{l}\text { Protein } \\
\text { ( } \mu \mathrm{g} / \text { embryo })\end{array}$ & $\begin{array}{l}\text { Number } \\
\text { of pooled } \\
\text { embryos }\end{array}$ \\
\hline \multicolumn{5}{|l|}{ Experiment 1} \\
\hline Insulin 0.1 & 15.2 & 129 & 896 & 7 \\
\hline 1 & 9.3 & 111 & 758 & 3 \\
\hline 5 & 7.7 & 75 & 577 & 2 \\
\hline Proinsulin 0.1 & 11.7 & 120 & 1287 & 8 \\
\hline 1 & 9.0 & 156 & 1530 & 8 \\
\hline 5 & 9.3 & 94 & 1038 & 9 \\
\hline Control & 14.9 & 118 & 928 & 3 \\
\hline \multicolumn{5}{|l|}{ Experiment 2} \\
\hline Insulin 0.1 & 12.8 & 160 & 664 & 3 \\
\hline 1 & 6.7 & 63 & 630 & 2 \\
\hline 5 & 6.4 & 62 & 620 & 1 \\
\hline Proinsulin 0.1 & 11.5 & 116 & 1092 & 4 \\
\hline 1 & 10.0 & 124 & 1060 & 3 \\
\hline 5 & 4.0 & 8 & 160 & 1 \\
\hline Control & 14.2 & 161 & 1376 & 5 \\
\hline
\end{tabular}

Groups of six to 12 embryos were injected with each dose of peptide; only embryos surviving after injections were pooled for determinations

(Fig. 1). Bovine insulin injected in the same dose-range gave effects almost identical to those of pork insulin (mean \pm SEM dead embryos: $30 \pm 7 \%$ with $0.1 \mu \mathrm{g}$ of bovine insulin, $58 \pm 4 \%$ with $1 \mu \mathrm{g}$ and $90 \pm 7 \%$ with $25 \mu \mathrm{g}$ ). Control groups injected with $\mathrm{HCl}, 1-100 \mu \mathrm{g}$ BSA or $100-500 \mu \mathrm{g}$ guinea-pig IgG showed low non-specific abnormalities; in all cases $<30 \%$ of embryos were affected. The lethality induced by insulin was appreciably reduced when insulin was immunoprecipitated by antiinsulin antibodies but not by normal guinea-pig $\operatorname{IgG}$. When a dose of $1 \mu \mathrm{g}$ insulin was pre-incubated with anti-insulin $\mathrm{IgG}$, the mean percentage of deaths in two experiments was $12.5 \%$. When insulin was pre-incubated with control $\mathrm{IgG}, 54 \%$ of embryos were dead.

\section{Relative potency of insulin related peptides}

Doses of proinsulin from 0.1 to $50 \mu \mathrm{g} / \mathrm{embryo}$ also produced high lethality and abnormal embryo growth, 


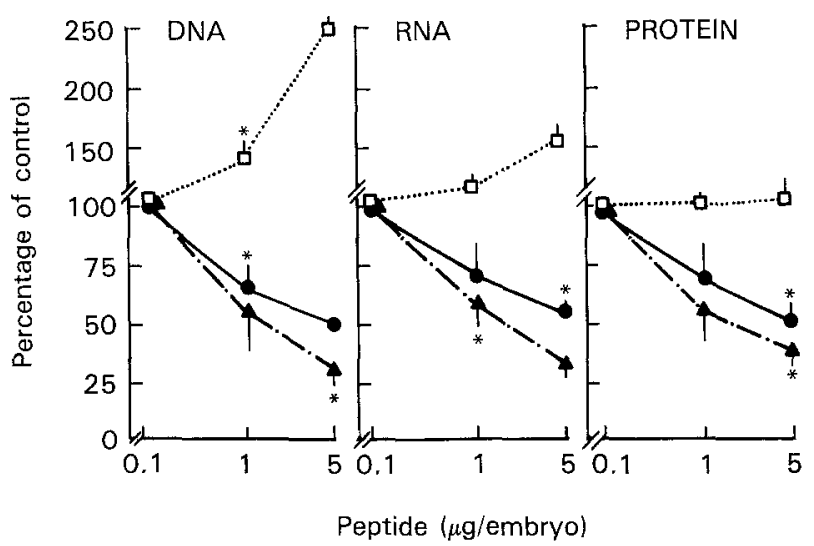

Fig.4. DNA, RNA, and protein content in surviving embryos at 4 days of development. Treatment at day 2 was insulin (- insulin $+10 \mathrm{mg}$ glucose $(\boldsymbol{\Delta}-\cdot \mathbf{\Delta})$, or MSA $(\square \cdots \cdots \square)$. In each case the value is expressed as a percentage of the content in embryos treated with the low dose $(0.1 \mu \mathrm{g} /$ embryo $)$ of the respective peptide. The values shown represent the mean \pm SEM of two to four determinations in pools of surviving embryos from different experiments (aproximate total number of embryos $=210$ ). $*$ indicates the lowest dose of peptide causing a significant change $(p<0.05)$

even though its metabolic potency is only $2-3 \%$ that of insulin [25]. Two lots of proinsulin, porcine and bovine, were equally potent. DOP was tested up to $25 \mu \mathrm{g} / \mathrm{em}-$ bryo. A significant percentage of altered embryo development followed $(53 \pm 9 \%$ deaths with a $25 \mu \mathrm{g}$ dose, $\mathrm{p}<0.05$ ). In vitro, however, DOP has only approximately $0.4 \%$ metabolic potency, but $30 \%$ growth potency of insulin [25]. MSA (0.05-5 $\mu \mathrm{g} /$ embryo) was even more potent than insulin in affecting embryogenesis, although its insulin-like metabolic effects were $0.2 \%$ compared with insulin [25] (Fig. 1). Figure 2 compares the untoward effects of insulin and related peptides upon embryogenesis. $\mathrm{LD}_{50}$ and $\mathrm{ED}_{50}$ were calculated for all peptides and the order of potency was: MSA $>$ insulin $>$ proinsulin $>$ DOP (Fig. 2 and Table 1). MSA was only $85 \%$ pure, according to the manufacturer and each $10 \mu \mathrm{g}$ vial also contained $100 \mu \mathrm{g}$ sodium acetate. For control purposes, an appropriate concentration of sodium acetate was injected demostrating a low nonspecific effect. In an additional single experiment "MSA-peak II" (kindly supplied by Dr. M. M. Rechler, National Institutes of Health Bethesda, Maryland) was injected. The lethal effect was only $50 \%$ as high as with MSA. The reason for this discrepancy was not immediatly clear and more experiments with MSA peak II are necessary.

\section{Influence of glucose on the effects of insulin}

D-glucose administered to the embryos simultaneously with insulin did not decrease the abnormalities (data not shown) or lethality caused by insulin (Fig. 3). Further, when the same doses of D-glucose $(1 \mathrm{or} 10 \mathrm{mg} / \mathrm{em}$ bryo) were injected alone, lethality was also evident, with approximately $40 \%$ of embryos affected.

\section{$D N A, R N A$ and protein content of embryos}

In embryos surviving injection with $5 \mu \mathrm{g}$ of insulin, the contents of DNA, RNA and protein were reduced by $49 \%, 40 \%$ and $48 \%$, respectively, when compared with the group injected with $0.1 \mu \mathrm{g}$ insulin (Table 2, Fig. 4). The effect of insulin was not corrected by the simultaneous addition of D-glucose. On the contrary, D-glucose $(10 \mathrm{mg})$ added to insulin further decreased these values. Injection of proinsulin ( $5 \mu \mathrm{g} /$ embryo) similarly decreased DNA by $43 \%$, RNA by $58 \%$ and protein by $53 \%$ compared with the $0.1 \mu \mathrm{g}$ proinsulin dose (Table 2 ). Interestingly, MSA at $5 \mu \mathrm{g} /$ embryo increased the DNA content of the embryos approximately 2.5 -fold ( $247 \%)$, with a small increase in RNA (154\%) and negligible change in total protein $(113 \%)$.

\section{Discussion}

Insulin has been reported to be a teratogen for young vertebrate embryos $[11,26,27]$. However, neither the mechanism of action nor the physiological role of insulin in early embryogenesis have been elucidated. Pharmacological doses of insulin have been shown to elicit classic effects later in embryogenesis. For example, hypoglycaemia was induced by exogenous insulin in chick embryos after day 6 of development [28]. Our characterization of mortality and morbidity caused by pharmacological doses of insulin and related peptides, in the most active period of differentiation in the chick, supports the hypothesis of a potential action of insulin on early developmental events in vivo; i.e. pharmacological doses of insulin are harmful for embryo development but this, of course, does not mean that insulin in physiological doses is harmful. It clearly indicates that the pathways of insulin action are functional in early embryogenesis.

We have extended Landauer's pioneer experiments on the teratogenicity of insulin in chick embryos [8] by using purified insulin of two different species. Both porcine and bovine insulins gave essentially identical results. That the effects of insulin were not merely due to its proteic nature was further substantiated by injecting other proteins, such as bovine serum albumen and normal guinea-pig IgG, which had little effect. Proinsulin and MSA relative potencies interfering with embryo growth were comparable to their potencies in other growth bioassays.

There is evidence from many systems that insulin and proinsulin cross-react significantly with receptors for the structurally related insulin-like growth factors, while the latter react weakly with the insulin receptor [29]. Studies in vitro on the growth and differentiationpromoting effects of insulin indicate that insulin generally acts through a growth receptor instead of through the insulin receptor $[18,29,30]$, with a few exceptions [31]. We postulate that the pharmacological effects of 
insulin in early chick embryos may be mediated by an insulin-like growth factor receptor similar to that described in older embryo fibroblasts [32]. Preliminary experiments have confirmed that such receptors are already present at day 2 of development in the chick [33]. Although indirect, our data support this hypothesis: (a) the order of potencies of the peptides altering embryo development was MSA > insulin > proinsulin > DOP. This is the order of affinity of these peptides for binding to insulin-like growth factor receptors in vitro, and it is very different from that for the insulin receptor. In addition, it parallels their potencies to elicit biological effects through the insulin-like growth factor receptors [29]. (b) the dose-range and potencies of insulin, proinsulin and MSA in our system are comparable to their potencies in other growth bioassays [34, 35], and compatible with a growth-receptor mediated effect. (c) that insulin's teratogenic effect on embryos was due to low glucose supply is unlikely. Glucose content (approximately $150 \mathrm{mg}$ ) in egg albumen [36] is readily available to the embryo in this type of in ovo culture. The addition of 1 or $10 \mathrm{mg}$ of D-glucose plus insulin did not reverse the deleterious effects of insulin but, in fact, increased the percentage of affected embryos. (d) the decrease in DNA, RNA and protein content in the surviving embryos treated with insulin could reflect arrested cell multiplication or a decrease in nucleic acid synthesis, suggestive of a growth rather than a metabolic effect of insulin. This decrease also was induced by high doses of proinsulin. In contrast to most reports describing the stimulatory effects of insulin in protein, DNA synthesis and ultimately cell growth, there have been other demonstrations of inhibitory effects of insulin at high concentrations, in acellular systems [37], melanoma cells [38] and also cultured chick embryos [39]. A hypothetical mechanism by which insulin, proinsulin and DOP in vast doses could reduce DNA, RNA and protein synthesis could be the competitive inhibition of binding of endogenous growth factors in the embryo.

MSA lethality, on the other hand, can be interpreted as embryo death raised by a growth stimulus inappropriately high for the specific developmental stage. Nevertheless, it is paradoxical that changes in DNA and RNA in the embryos are divergent, if insulin appears to act through the same receptor as MSA interfering with embryogenesis. This probably reflects complex interactions between insulin and insulin-like growth factor receptors, which require further experiments in vitro.

The other possibilities, that the injected peptides act through the insulin receptor or through both insulin and insulin-like growth factor receptors, could still be true if proinsulin and DOP have much longer half-life than insulin in the embryo environment. In this case, they would appear to exert a greater potency with respect to insulin when acting through the insulin receptor. But, in fact, in our previous work we were not able to demonstrate the presence of insulin receptors at 2 days of development in the chick. On the other hand, our data confirm earlier findings where changes in glucose were not considered to play an important role in insulin-induced malformations [11, 27], and also reflect that glucose itself may be toxic for developing embryos. This latter aspect has been known for several years [36], and although it is not the focus of our work, it has relevant implications for the abnormal development of infants of diabetic mothers.

We postulated a developmental role for insulin in embryogenesis after showing that insulin and insulin receptors were present very early in chick embryos. We now suggest that untoward pharmacological effects of insulin, during the period of differentiation of the chick, are probably mediated by insulin binding to or modulation of insulin-like growth factor receptors. We have not yet proved that insulin has any physiological role in development of vertebrate embryos, an aspect that certainly deserves future investigation.

Acknowledgements. We are very grateful to Drs. J. Roth and M. A. Lesniak, Diabetes Branch, National Institutes of Health, Bethesda, Maryland, USA for their technical advice and continuous encouragement during this study. We also thank Drs. R.E.Chance and M.M. Rechler for their generous gift of peptides, Dr. J.M.Queraltó for his assistance with the computer analysis, and Dr. A. Garcia for critical review of manuscript. This study was supported by grants from the Kroc Foundation, California, (F. de P.), FISS-83/0807, Madrid (F. de P.) and CIRIT-AR 83-84, Barcelona (E.H.)

\section{References}

1. Pedersen J (1977) The pregnant diabetic and her newborn, 2nd. ed. Williams \& Wilkins, Baltimore

2. Sosenko IR, Kitzmiller JL, Loo SW, Blix P, Rubenstein AH, Gabbay KH (1979) The infant of the diabetic mother: correlation of increased C-peptide levels with macrosomia and hypoglycemia. N Engl J Med 301: 859-862

3. Gabbe SG, Lowensohn RI, Wu PYK, Guerra G (1978) Current patterns of neonatal morbidity and mortality in infants of diabetic mothers. Diabetes Care 1: 335-339

4. Mills JL, Baker L, Godman AS (1979) Malformation in infants of diabetic mothers occur before the seventh gestational week. Diabetes $28: 292-293$

5. Miller E, Hare JW, Cloherty JP, Dunn PJ, Gleason RE, Soeldner JS, Kitzmiller JL (1981) Elevated maternal hemoglobin $A_{1 c}$ in early pregnancy and major congenital anomalies in infants of diabetic mothers. N Engl J Med 304: 1331-1334

6. Horton WE, Sadler TW (1983) Effects of maternal diabetes on early embryogenesis. Alterations in morphogenesis produced by ketone body, $\beta$-hydroxybutyrate. Diabetes $32: 610-616$

7. Bauman WA, Yalow R (1981) Transplacental passage of insulin complexes to antibody. Proc Natl Acad Sci USA. 78:4588-4590

8. Landauer W, Bliss CL (1946) Insulin induces rumplessness of chickens. J Exp Zool 102: 1-22

9. Duraiswani PK (1950) Insulin induced skeletal abnormalities in developing chickens. Br Med J 2: 384-390

10. Zwilling E (1959) Micromelia as a direct effect of insulin. Evidence from in vitro and in vivo experiments. J Morph 104: 159-179

11. Landauer W (1972) Is insulin a teratogen? Teratology 5: 129-135

12. Kahn CR, Baird KL, Flier JS, Grunfeld C, Harmon JT, Harrison LC, Karlsson FA, Kasuga M, King GL, Lang UC, Podskalny JM, Van Obberghen E (1981) Insulin receptors, receptor antibodies, and the mechanism of insulin action. Rec Prog Horm Res 37: $477-538$ 
13. Susa JB, McCormick KL, Widness JA, Singer DB, Oh W, Admons K, Schwartz R (1979) Chronic hyperinsulinemia in the fetal Rhesus monkey. Effects on fetal growth and composition. Diabetes 28: 1058-1063

14. Angervall L, Karlsoon, K, Martinsson A (1981) Effects on the rat fetuses of intrauterine injections of insulin. Diabetología 20: $558-562$

15. Bolander FF, Nicholas KR, Van Wyk JJ, Topper YJ (1981) Insulin is essential for accumulation of casein mRNA in mouse mammary epithelial cells. Proc Natl Acad Sci USA 78: 5682-5684

16. Milstone LM, Piatagorsky J (1977) Delta-crystalline gene expression in embryonic chick lens epithelia cultured in the presence of insulin. Exp Cell Res 105: 9-14

17. El-Etr M, Schorderet-Slatkine S, Baulieu EE (1979) Meiotic maturation in "Xenopus laevis oocytes" initiated by insulin. Science 205: 1397-1399

18. Maller JL, Koontz JW (1981) A study of the induction of cell division in amphibian oocytes by insulin. Develop Biol 85:309-316

19. De Pablo F, Roth J, Hernandez E, Pruss RM (1982) Insulin is present in chicken eggs and early chick embryos. Endocrinology 111: 1909-1916

20. Hendricks SA, De Pablo F, Roth J (1984) Early development and tissue specific patterns of insulin binding in chick embryo. Endocrinology 115: 1315-1323

21. Romanoff AL (1931) Cultivation of the chick embryo in an opened egg. Anat Rec 48: 185-189

22. Hamburger V, Hamilton HL (1951) A series of normal stages in the development of the chick embryo. J Morphol 88: 49-92

23. Bradford MM (1976) A rapid and sensitive method for the quantitation of microgram quantities of protein utilizing the principle of protein dye binding. Anal Biochem 72: 248-254

24. Boer GJ (1975) A simplified microassay of DNA and RNA using ethidium bromide. Anal Biochem 65: 225-231

25. King GL, Kahn CR (1981) Non-parallel evolution of metabolic and growth-promoting functions of insulin. Nature 292: 644-646

26. Lichtenstein H, Guest GM, Warkany $\mathbf{J}$ (1951) Abnormalities in offspring of white rats given protamine-zinc insulin during pregnancy. Proc Soc Exp Biol Med 78: 398-402

27. Cole WA, Trasler DG (1980) Gene-teratogen interaction in insulin induced mouse exencephal. Teratology 22:125-139

28. Zwilling E (1948) Insulin hypoglycemia in chick embryos. Proc Soc Exp Biol Med 67: 192

29. Rechler MM, Nissley SP, King GL, Moses AC (1981) Multiplication stimulating activity (MSA) from the BRL-3A rat liver cell line: relation to human somatomedins and insulin. J Supramol Str Cell Bioch 15: 252-286
30. King GL, Kahn CR, Rechler MM, Nissley SP (1980) Direct demonstration of separate receptor for growth and metabolic activities of insulin and multiplication-stimulating activity (an insulin-like growth factor) using antibodies to the insulin receptor. J Clin Invest $66: 130-140$

31. Nagarajan L, Anderson WB (1982) Insulin promotes the growth of F9 embryonal carcinoma cells apparently by acting through its own receptor. Biochem Biophys Res Commun 106: 974-980

32. Kasuga M, Van Obberghen E, Nissley SP, Rechler MM (1981) Structure of the insulin-like growth factor receptor in chicken embryo fibroblast. Proc Natl Acad Sci USA 79: 1864-1868

33. Bassas L, De Pablo F, Lesniak MA, Roth J (1984) Receptors that prefer insulin-like growth factors antedate the insulin receptor during organogenesis of chick. J Esteroid Biochem 20: 1423 (Abstract)

34. Nissley SP, Rechler MM, Moses AC, Short PA, Podskalny JM (1977) Proinsulin binds to a growth peptide receptor and stimulates DNA synthesis in chick embryo fibroblasts. Endocrinology 101: 708-716

35. Adams LO, Nissley SP, Kasuga M, Foley TP, Rechler MM (1983) Receptors for insulin-like growth factors and growth effects of multiplication-stimulating activity (rat insulin-like growth factor II) in rat embryo fibroblasts. Endocrinology 112: 971-978

36. Hughes AF, Freeman RB, Fadem T (1974) The teratogenic effects of sugars on the chick embryo. J Embryol Exp Morphol 32: $661-674$

37. Schumm DE, Webb TE (1981) Insulin modulated transport of RNA from isolated liver nuclei. Arch Biochem Biophys 210: 275-279

38. Fuller BB, Ehlers SE (1984) Insulin mediated inhibition of tyrosinase activity and protein synthesis in melanoma cell cultures. Endocrinology 114: 222-226

39. Hickey ED, Klein NW (1971) Changes in DNA, RNA and protein content of regions of explanted chicken embryos following insulin treatment. Teratology $4: 453-460$

Received: 17 May 1984

and in revised form: 20 February 1985

Dr. Flora de Pablo

Servicio de Endocrinología

Hospital de la Santa Cruz y San Pablo

Ave. S. Antonio M. Claret, 167

Barcelona - 25

Spain 